\title{
The Contribution of Self-Esteem and Parenting towards Aggressive Behavior of Child Victims' Domestic Violence
}

\author{
Opi Andriani ${ }^{1}$, Alizamar $^{1}$, Yeni Karneli ${ }^{1}$ \\ ${ }^{1}$ Universitas Negeri Padang \\ Corresponding author, e-mail: opi.adr@gmail.com
}

\begin{abstract}
Children who live in violent environments have aggressive tendencies as a result of the interaction process. Aggressive behavior of children is influenced by several factors such as improper care, stress, low self-esteem, bad relationships and the display of violence in the mass media. This research aims at examining the contribution of self-esteem and parenting to the aggressive behavior of child victims of domestic violence. The research used a quantitative approach with a descriptive and correlation type. The research respondents were the students of SMA Negeri Padang who were identified as 73 victims of domestic violence victims, selected by using a purposive sampling technique. The data were collected using the CFSEI-2 inventory for self-esteem and Likert model scale for aggressive behavior with a reliability level of 0.899 and 0.915 for parenting. The data processing used a multiple regression analysis technique with the help of SPSS for Windows Release 20. The findings of this research indicated that self-esteem and parenting together contributed to the aggressive behavior of child victims of domestic violence by $41.7 \%$.
\end{abstract}

Keywords: Self-Esteem, Parenting, Aggresive Behavior, Domestic Violence

How to Cite: Andriani, O., Alizamar, A., Karneli, Y. (2020). The Contribution of Self-Esteem and Parenting towards Aggresive Behavior Child Victims' Domestic Violence. International Journal of Research in Counseling and Education, 4(1), 21-27

\section{Introduction}

Violence that occurs in households is still considered a taboo domestic event to be discussed openly in the community. Domestic violence (KDRT) is generally carried out by one family member against other family members as a form of verbal and non-verbal behavior that has a negative physical and psychological effect on the target (Eze Eze, 2019; Forke, Catallozzi, Localio, Grisso, Wiebe, \& Fein, 2019; Rianawati, 2015; Wicaksana, 2008). Domestic violence can occur in every family member such as husband, wife and/or children (Draxler, Hjärthag, \& Almqvist, 2019).

Afdal, Alizamar, Ifdil, Erlamsyah, \& Taufik, (2017) explained that KDRT can occur in all family members, especially in women and children. Nevertheless, in general, many victims of domestic violence happen to women who have the position as a wife or mother in the household. Law Number 23 Year 2004 Article 1 Paragraph 1 concerning the Elimination of Domestic Violence explains that domestic violence is an act committed on women that causes physical, sexual, psychological and / or neglect of the household. Based on this definition, it is understood that domestic violence can occur to anyone, especially those who are physically and mentally weak such as husbands to wives.

In his research, Ramadhan (2017) revealed that in households there were $82.7 \%$, physical violence, $78 \%$, psychological violence, $72.7 \%$, sexual violence, $82.1 \%$, neglect of households, $80.3 \%$ threats to carry out coercion or appropriation with respondents 36 woman. Based on this it can be understood that violence can occur in the household in the form of physical, psychological, and welfare violence so as to have a serious impact on various aspects of family life. This means that the impact of violence on one family member can be felt by other family members such as children.

In addition, Oshio \& Umeda (2016) revealed that parental behavior has a greater effect on the development of children of the same sex. Hornor (2005) mentions that more than 3 million American children aged 3 to 17 years witness violence every year. Bair-Merritt, Blackstone, \& Feudtner (2006); 
Mardiyati (2015) revealed that children who witness violence in their family are vulnerable to physical and psychological disorders that affect changes in behavior patterns. This is due to the experience gained can form thought patterns and patterns of children's behavior. Djamarah (2004) asserts that the experiences gained by children will cause reactions that have an impact on behavior. One of these behaviors can be aggressive behavior.

Moreover, Cao, Li, Zhao, Zhang, Guo, Zhang, \& Luo (2016); Manumpahi, Goni, \& Pongoh (2016) revealed that domestic violence has a negative impact on children's behavior such as anxiety, depression, social interaction problems, attention problems, delinquency, aggression, and externalization. Based on this description, it can be understood that domestic violence can have a direct or indirect impact on children. This can occur due to the experience, learning and imitation of behavior that occurs in children. One of the effects of domestic violence is the presence of aggressive behavior displayed by children. Aggressive behavior is sending dangerous stimuli to others without being linked to intentions carried out in physical or verbal form directly or indirectly (Karneli, 2019). That is, aggressive behavior can be done intentionally or unintentionally but the impact is felt by the victim such as being hurt physically and psychologically. Some experts define aggressive behavior as an action that intends to hurt others physically or psychologically (Atkinson, Atkinson, \& Hilgard, 1983; Rahman, 2013).

Zulaiha, Husen, \& Bakar (2019) explained that the types of behavior that occur in aggressive children such as being angry, damaging other people's objects, fighting, arrogant, seeking attention, being easily distracted, jealous, cruel, irresponsible, irresponsible and speaking harshly. Buss \& Perry (1992) divert forms of aggressive behavior consisting of physical, verbal, angry and hostile aggression. All forms of aggressive behavior have a dominant nature of harming others. Every behavior has an impact on the perpetrators and their victims. The impact on the offender, for example the offender will be shunned and not liked by others due to the difficulty of establishing healthy interpersonal relationships. While the impact on victims, for example the emergence of physical and psychological pain and losses due to aggressive behavior (Kartono, 2005; Rahmawati \& Asyanti, 2017). Aggressive behavior can also cause a decrease in student learning outcomes for victims (Saputra, Hanifah, \& Widagdo, 2017). Furthermore, aggressive behavior is significantly able to change the school climate from a psychological perspective to being less conducive to the impact on decreasing student achievement(MacNeil, Prater, \& Busch, 2009).

Child victims of domestic violence are able to apply the right behavior despite being in an unhealthy family condition because there are several things that affect aggressive behavior to be formed and increased. There are various internal and external factors that influence aggressive behavior which include conditions in individuals (such as self-esteem, self-control), family / parents, peers, social environment / neighbors (Apollo \& Ancok, 2003; Susantyo, 2018). Restu, Yusri, \& Ardi (2013) explain that aggressive behavior can be caused by various factors, such as feeling under-attention, improper care, stress, bad relationships and the effects of violence in the mass media. From the description above there are conditions in the individual; one of them is self-esteem. Having problematic self-esteem can interfere with the process of interaction with yourself and others. This is due to self-esteem can be in the form of an evaluation or assessment of oneself based on views of oneself and judgments about views according to others about oneself.

Every individual needs to have high self-esteem for the success and happiness of his life (Rhepon \& Nirwana, 2016). Someone who has a positive assessment will feel himself valuable, able to respect others and appreciate the conditions they face. Meanwhile, someone who has low self-esteem will behave aggressively as a motive to increase his self-esteem (Donnellan, Trzesniewski, Robins, Moffitt, \& Caspi 2005). Fauziyah (2018) stated that aggressive behavior can be formed due to low self-esteem. Having low self-esteem is likely to do acts referring to aggression aimed at gaining recognition and increasing self-esteem.

In addition to self-esteem, parenting can also influence aggressive behavior. As one of the external factors that tends to be present in the family environment, caring for people is very important to be a concern. Baumrind (1971) ) revealed that the primary role of parents is to influence, teach, and control children. Coopersmith revealed the role of family and the relationship between parents, parents and children as well as between children is quite large in the formation of personality, peace of mind, confidence, and finally the development of appropriate behavior and reduce mental disorders (Moghaddam, Validad, Rakhshani, \& Assareh, 2017). If parents apply bad care, conflict will occur in the child. Parental care has an important role in the formation of behavior. Parenting refers to the practices adopted by parents during the growth and development of their children at the stage of socialization as well as how children are controlled.

Parenting is a determining factor and plays an important role in children's development (Beato, Pereira, Barros, \& Muris, 2016; Özgür, 2016). Ideal parenting care is nurture in which there is an element of education that can help the development of physical and psychological health, normative behavior. Children who have good care will apply good behavior when interacting with others. Improper or inappropriate care will form aggressive child hehavior This is consistent with the opininn of Trenas, Félix, Osuna, José, \& Herruzo (2009) 
which revealed aggressive behavior influenced by how parenting was applied by parents. However, not all parents are aware and able to apply good care. This is inseparable from the condition of the household which is sometimes the reason for the neglect of children's right to develop optimally (Pesce, 2009). Uncertain, deficient and complicated situations make parents stressed so they tend to be rude and ignore the child's developmental needs (Widiastuti \& Sekartini, 2016). Though improving the quality of parenting during adolescence can reduce problematic behavior in children.

Research by Guswani \& Kawuryan (2011) ) revealed that the level of aggressive behavior was in the very high category of 13 people (8.67\%); high 33 people (22,\%), moderate 51 people (34\%), low 48 people (32\%), and very low 5 people (3.33\%). Furthermore, Alizamar, Syahputra, Afdal, Ardi, \& Trizeta (2018) revealed that some aggressive behaviors tend to be displayed by boys and girls such as being physically aggressive by showing direct anger (hitting, kicking, pushing while insulting). While verbal aggression is shown with the intention to hurt such as gossip, exclusion and prejudice that tends to be done by girls. The results of Aulya, Ilyas, \& Ifdil (2016) research revealed that the majority of teenage boys have high aggressive behavior compared to girls. Pratama, Karneli, \& Syahniar (2016) explain that aggressive actions such as attacking and damaging tend to be done by children who come from problematic families.

Based on the description and phenomenon above, Alizamar, Syahputra, Afdal, Ardi, \& Trizeta (2018) explain that aggressive behavior that occurs among students can show a decrease in the quality of education. This is caused by various impacts caused by adolescents who have a tendency to behave aggressively such as experiencing learning disabilities, interpersonal problems (Wilson, 2003) and have low social skills (Hann, 2002). The results of Gentile, Lynch, Linder, \& Walsh (2004) research explained that children who behave aggressively generally have low academic achievement and have learning difficulties. So it needs various institutions or institutions such as schools that have the authority to solve or alleviate problems that occur, but in reality are not yet comprehensive.

Professional counselors have the authority to provide guidance and counseling services for child victims of domestic violence. Furthermore, being able to prevent acts of violence and reduce the aggressive behavior of students in school by utilizing various approaches in counseling (Karneli, 2019). Some possible conditions that can influence this behavior need to be discussed more deeply as a basis for determining appropriate steps in reducing aggressive behavior in child victims of domestic violence. Based on the description and results of the research that has been described, violence that occurs in households tends to occur against women or mothers of children victims of domestic violence. Therefore, this study will look at the contribution of self-esteem and parenting to aggressive behavior in child victims of domestic violence.

\section{Method}

This research was a quantitative study using the correlation method. The respondents of this research were the students of SMA N 7 Padang in the 2019-2020 academic year. The respondents of this study were taken using a purposive sampling technique by identifying child victims of domestic violence based on a needs study questionnaire, so that respondents were obtained 73 students. The data collection used three instruments: 1) Aggressive Likert scale instrument which is an adoption instrument from Karneli (2019) which has tested the validity with alpha crombach reliability level of $0.899,2$ ) The Culture Free Self Esteem (CFSEI-2) for measuring self-esteem is an instrument of adoption from Battle by Marjohan (1997) which has been tested for validity with a reliability level of $0.72,3$ ) parenting instruments on a Likert scale model have tested the validity with an alpha crombach reliability level of 0.915 . The data processing research results were analyzed by using a multiple regression analysis with the help of the SPSS for Windows Release 20 program. 


\section{Results}

The results of the analysis of the contribution of self-esteem and parenting together to the aggressive behavior of child victims of domestic violence can be seen in Table 1 .

Table 1. The Results of Multiple Regression Analysis and the Significance of Self-Esteem and Parenting Towards Aggressive Behavior of the Victim's Child Domestic Violence

\begin{tabular}{cccc}
\hline Variabel & $\mathbf{R}$ & $\mathbf{R}$ Square & Sig. \\
\hline $\mathrm{X}_{1} \mathrm{X}_{2}-\mathrm{Y}$ & 0.645 & 0.417 & 0.000 \\
\hline
\end{tabular}

Based on Table 1 it can be seen that the multiple regression coefficients X1 and X2 against Y obtained R of 0.645 with a significance level of 0.000 , the coefficient (R2) square of 0.417 . This means that self-esteem and parenting strongly correlate to the aggressive behavior of child victims of domestic violence with a contribution of $41.7 \%$ and the rest is influenced by other factors. Furthermore, to find out the form or direction of contribution between variables can be seen in the simple regression equation in Table 2.

Table 2. The Results of Multiple Regression Analysis of the Contribution of Self Esteem and Parenting Together Against Aggressive Child Behavior Victims of domestic violence

\begin{tabular}{|c|c|c|c|c|c|c|}
\hline \multicolumn{2}{|r|}{ Model } & \multicolumn{2}{|c|}{ Unstandardized Coefficients } & \multirow{2}{*}{$\begin{array}{c}\text { Standardized } \\
\text { Coefficients } \\
\text { Beta }\end{array}$} & \multirow[t]{2}{*}{$\mathrm{T}$} & \multirow[t]{2}{*}{ Sig. } \\
\hline & & B & Std. Error & & & \\
\hline \multirow{3}{*}{1} & (Constant) & 228.554 & 14.925 & & 15.313 & 0.000 \\
\hline & Self-esteem & -1.298 & 0.422 & -0.301 & -3.074 & 0.003 \\
\hline & Parenting & -0.526 & 0.109 & -0.473 & -4.835 & 0.000 \\
\hline
\end{tabular}

Information:

$\mathrm{B}$ : The direction value as a predictor (prediction)

$\mathrm{t}$ : Test the coefficient $\mathrm{t}$

Sig: Significance of the relationship between variables

Based on the results of the multiple regression analysis in Table 3 it can be seen that self-esteem obtained a $B$ value of $-1,298$. That is, self-esteem contributes negatively to the aggressive behavior of child victims of domestic violence by $-1,298$. Then, parenting has a value of -0.526 . This means that having parental care contributes negatively to the aggressive behavior of child victims of domestic violence of $-0,526$. Thus, it can be seen that self-esteem and parenting are increasing, so the aggressive behavior of child victims of domestic violence decreases. Furthermore, the analysis of regression results can be described as the following regression equation.

$\hat{Y}=a+b_{1} X_{1}+b_{2} X_{2}$
$\hat{Y}=228.554+\left(-1.298 X_{1}\right)+\left(-0.526 X_{2}\right)$

The equation model implies, that 1) The constant value (a) was 228,554; it means that if self-esteem and parenting are 0 . Then, aggressive behavior was $228,554,2$ ). The value of the regression coefficient of selfesteem (b1) was negative; it means that every improvement in self-esteem equal to 1 will reduce aggressive behavior by -1,298 assuming other variables are fixed, 3) The parenting regression coefficient value (b2) was negative; it means that each parenting by 1 will decrease aggressive behavior by -0,526 assuming other variables are fixed. The results of testing the above hypothesis can be concluded that the results of the study in the form of a chart "contribution of self-esteem and parenting parents to aggressive behavior" as shown below.

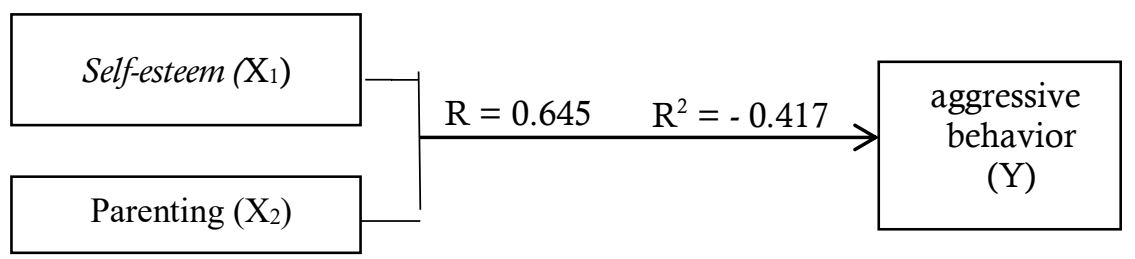

Figure 1. The Contribution of Self-esteem $\left(\mathrm{X}_{1}\right)$ and Parenting $\left(\mathrm{X}_{2}\right)$ to Aggressive Behavior $(\mathrm{Y})$

\section{Discussion}

(The Contribution of Self-Esteem and Parenting towards Aggresive Behavior Child Victims' Domestic 
Based on the results of the study found that self-esteem and parenting together contribute to the aggressive behavior of child victims of domestic violence in SMA N 7 Padang. This finding was obtained based on a series of data analyzes which showed that self-esteem and parenting together contributed to aggressive behavior by $41.7 \%$. This means that self-esteem and parenting together can contribute to the aggressive behavior of child victims of domestic violence by $41.7 \%$. The results of this study are supported by Hornor (2005) who explains that domestic violence puts children at risk physically, emotionally, and developmentally.

Based on this it can be understood that each individual is able to develop positive behavior even in a stressful environment such as violence. This can happen if the child development stage has a high level of esteem and is supported by good parenting. Rakhmat (2005) revealed that self-esteem is one of the causes of aggressive behavior. Low self-esteem can be caused by a negative assessment of them so to make themselves valuable they need recognition from others. Therefore, child victims of domestic violence tend to adopt aggressive behavior can be indicated as individuals who have low self-esteem.

In addition, poor parenting can also contribute to improved aggressive behavior. Applying care that is not in accordance with their needs and development can make children behave negatively like aggressively. Puspita, Erlamsyah, \& Syahniar (2013) explained that parents must be able to provide appropriate care in accordance with their child's development, so that children can perceive the actions given to them properly so that they can behave in accordance with the demands of their development. This opinion can be understood that parenting is one form of support for children in behavior. However, in an uncertain situation, being completely deficient and complicated makes parents stressed so they tend to be rude and ignore the child's developmental needs (Widiastuti \& Sekartini, 2016). Parents may neglect their children's physical and psychological needs as a result of the violence they experience in the home. Based on the description, it can be concluded that in bad environmental conditions children can implement positive behavior if they have good self-esteem and good parenting.

In this case, Coopersmith argues that high self-esteem tends to be related to the parenting characteristics applied by parents, as follows: (a) expressing affection, caring for the problems experienced, (b) harmony in the family, (c) participation in family activities, (d) provide adequate and organized assistance in accordance with what is needed, (e) there are clear and fair rules for parents and children, (f) refer to the rules that have been made, (g) provide freedom within the boundaries clear (Santrock, 2007). Thus, it can be understood that good parenting not only contributes to aggressive behavior but also to self-esteem.

Wilburn \& Smith (2005) revealed that positive self-esteem increases one's ability to cope with stress and eliminate bad thoughts. If self-esteem is good, it will contribute to aggressive behavior in the school and community environment. Understanding of children in schools must be controlled and directed by parents, especially mothers who are closest to children. Mudjiran, Hartati, \& Rinaldi (2018) explain that ideal care should be applied by every parent by meeting physical and psychological needs in accordance with the stage and task of child development. Then, it is assisted by the school so as to reduce the level of aggressive behavior in the school. The results of this study can also confirm that there are several factors that can influence aggressive behavior, including self-esteem and parenting. Furthermore, from the results of the hypothesis, it could be a reference for BK/Counselor teachers in carrying out guidance and counseling services in schools.

\section{Conclusion}

Based on the findings and discussion of the results of the study, it can be concluded that self-esteem and parenting together have a strong contribution to the aggressive behavior of child victims domestic violence. This means that if the individual has high self-esteem and good parenting, the aggressive behavior of child victims of domestic violence decreases. The limitation of this study is the number of research subjects obtained from schools so that characteristics only dominate in general, meaning that research with specific child samples needs to be supported by qualitative data that is revealed through interviews and a review of demographic data. Therefore, further researchers are suggested to be able to generalize this study using different research methods.

\section{References}

Afdal, A., Alizamar, A., Ifdil, I., Erlamsyah, E., \& Taufik, T. (2017). Guidance and counseling services for women victims of domestic violence. Advances in Social Science, Education and Humanities Research, 118(23), 935-939.

Alizamar, A., Syahputra, Y., Afdal, A., Ardi, Z., \& Trizeta, L. (2018). Differences in aggressive behavior of male and female students using Rasch stacking. International Journal of Research in Counseling and 
Education, 2(1), 22-32.

Apollo, D., \& Ancok. (2003). Hubungan antara intensitas menonton tayangan televisi berisi kekerasan, persepsi terhadap keharmonisan keluarga, jenis kelamin, dan tahap perkembangan dengan kecenderungan agresivitas remaja. Sosiohumanika, 16 A(2003).

Atkinson, R. L., Atkinson, R. C., \& Hilgard, E. R. (1983). Pengantar Psikologi (terjemahan). Jakarta: Penerbit Erlangga.

Aulya, A., Ilyas, A., \& Ifdil, I. (2016). Perbedaan perilaku agresif siswa laki-laki dan siswa perempuan. Jurnal EDUCATIO: Jurnal Pendidikan Indonesia, 2(1), 91-97.

Bair-Merritt, M. H., Blackstone, M., \& Feudtner, C. (2006). Physical health outcomes of childhood exposure to intimate partner violence: a systematic review. Pediatrics, 1172), e278-e290.

Baumrind, D. (1971). Current patterns of parental authority. Developmental Psychology, 4(1p2), 1.

Beato, A., Pereira, A. I., Barros, L., \& Muris, P. (2016). The relationship between different parenting typologies in fathers and mothers and children's anxiety. Journal of Child and Family Studies, 25(5), 1691-1701.

Buss, A. H., \& Perry, M. (1992). The aggression questionnaire. Journal of Personality and Social Psychology, 63(3), 452.

Cao, Y., Li, L., Zhao, X., Zhang, Y., Guo, X., Zhang, Y., \& Luo, X. (2016). Effects of exposure to domestic physical violence on children's behavior: a chinese community-based sample. Journal of Child \& Adolescent Trauma, 9(2), 127-135.

Djamarah, S. B. (2004). Pola komunikasi orang tua dan anak dalam keluarga (sebuah perspektif pendidikan Islam). Rineka Cipta.

Donnellan, M. B., Trzesniewski, K. H., Robins, R. W., Moffitt, T. E., \& Caspi, A. (2005). Low self-esteem is related to aggression, antisocial behavior, and delinquency. Psychological Science, 16(4), 328-335.

Draxler, H., Hjärthag, F., \& Almqvist, K. (2019). Replicability of effect when transferring a supportive programme for parents exposed to intimate partner violence and their children from the US to sweden. Child Care in Practice, 25(4), 367-382. https://doi.org/10.1080/13575279.2018.1463968

Eze Eze, D. (2019). Microfinance programs and domestic violence in northern cameroon; the case of the familial Rural income improvement program. Review of Economics of the Household, 173), 947-967. https://doi.org/10.1007/s11150-017-9393-x

Fauziyah, N. (2018). Self-esteem remaja yang mengalami kekerasan pada masa anak-anak. Tesis Tidak Diterbitkan. Universitas Airlangga.

Forke, C. M., Catallozzi, M., Localio, A. R., Grisso, J. A., Wiebe, D. J., \& Fein, J. A. (2019). Intergenerational effects of witnessing domestic violence: Health of the witnesses and their children. Preventive Medicine Reports, 15. https://doi.org/10.1016/j.pmedr.2019.100942

Gentile, D. A., Lynch, P. J., Linder, J. R., \& Walsh, D. A. (2004). The effects of violent video game habits on adolescent hostility, aggressive behaviors, and school performance. Journal of Adolescence, 271), 5-22.

Guswani, A. M., \& Kawuryan, F. (2011). Perilaku agresi pada mahasiswa ditinjau dari kematangan emosi. Jurnal Psikologi UMK: PITUTUR, 1(2), 86-92.

Hann, D. M. (2002). Taking stock of risk factors for child/youth externalizing behavior problems. Bethesda, Maryland: National Institute of Mental Healt.

Hornor, G. (2005). Domestic violence and children. Journal of Pediatric Health Care, 1944), 206-212.

Karneli, Y. (2019). Upaya Guru BK/Konselor untuk menurunkan perilaku agresif siswa dengan menggunakan konseling kreatif dalam bingkai modifikasi kognitif perilaku. Pedagogi, 18(2), 32-38.

Kartono, M. (2005). Perbandingan perilaku agresif antara remaja yang berasal dari keluarga bercerai dengan keluarga utuh. Jurnal Psikologi Vol, 3(1), 1.

MacNeil, A. J., Prater, D. L., \& Busch, S. (2009). The effects of school culture and climate on student achievement. International Journal of Leadership in Education, 12(1), 73-84.

Manumpahi, E., Goni, S. Y. V. I., \& Pongoh, H. W. (2016). Kajian kekerasan dalam rumah tangga terhadap psikologi anak di Desa Soakonora Kecamatan Jailolo Kabupaten Halmahera Barat. JURNAL ACTA DIURNA, 5(1).

Mardiyati, I. (2015). Dampak trauma kekerasan dalam rumah tangga terhadap perkembangan psikis anak. Raheema, 2(1).

Marjohan. (1997). An investigation of factors that influence decision making and their relationship to selfesteem an locus of control among Minangkabau students. Disertasi Tidak Diterbitkan. Tasmania: University of Tasmania.

Moghaddam, M. F., Validad, A., Rakhshani, T., \& Assareh, M. (2017). Child self-esteem and different parenting styles of mothers: a cross-sectional study. Archives of Psychiatry and Psychotherapy, 19(1), 37-42.

Mudjiran, M., Hartati, N., \& Rinaldi, R. (2018). Optimalisasi pengasuhan pada keluarga miskin dalam rangka meningkatkan kesejahteraan subyektif anak di Kota Padang. Jurnal RAP (Riset Aktual Psikologi Universitas Negeri Padang), 8(2), 158-169.

Oshio, T., \& Umeda, M. (2016). Gender-specific linkages of parents' childhood physical abuse and neglect with children's problem behaviour: evidence from Japan. BMC Public Health, 16(1), 403.

(The Contribution of Self-Esteem and Parenting towards Aggresive Behavior Child Victims' Domestic 
Özgür, H. (2016). The relationship between Internet parenting styles and Internet usage of children and adolescents. Computers in Human Behavior, 60, 411-424.

Pesce, R. (2009). Family violence and aggressive and oppositional behavior in childhood: A literature review . Ciencia E Saude Coletiva, 14(2), 507-518. Retrieved from https://www.scopus.com/inward /record.uri?eid=2-s2.0-67650321250\&partnerID=40\&md5=1d9718941e103fd579d854e556c338bd

Pratama, R., Karneli, Y., \& Syahniar, S. (2016). Perilaku agresif siswa dari keluarga broken home, 5(4), 238246.

Rahman, A. A. (2013). Psikologi sosial: integrasi pengetahuan wahyu dan pengetahuan empirik. Jakarta: Raja Grafindo Persada.

Rahmawati, A., \& Asyanti, S. (2017). Fenomena perilaku agresif pada remaja dan penanganan secara psikologis. Prosiding SEMNAS Penguatan Individu Era Revolusi Informasi.

Rakhmat, J. (2005). Psikologi Komunikasi. Bandung: Remaja Rosdakarya.

Ramadhan, R. A. (2017). Pengaruh Kekerasan dalam Rumah Tangga (Kdrt) terhadap Tingkat Keharmonisan dalam Keluarga di Kelurahan Umban Sari Kecamatan Rumbai Kota Pekanbaru. Jurnal Online Mahasiswa Fakultas IImu Sosial Dan Ilmu Politik Universitas Riau, 5(1), 1-15.

Restu, Y., Yusri, Y., \& Ardi, Z. (2013). Studi tentang perilaku agresif siswa di sekolah. Konselor, 2(1).

Rhepon, S., \& Nirwana, H. (2016). Pengembangan modul bimbingan dan konseling yang dapat digunakan guru Bimbingan dan Konseling atau Konselor untuk peningkatkan self-esteem ( penghargaan terhadap diri sendiri ) siswa, 5(1).

Rianawati, R. (2015). Perlindungan hukum terhadap kekerasan pada anak. Raheema, 2(1).

Santrock, J. W. (2007). Remaja. Jakarta: Erlangga.

Saputra, W. N. E., Hanifah, N., \& Widagdo, D. N. (2017). Perbedaan tingkat perilaku agresi berdasarkan jenis kelamin pada siswa sekolah menengah kejuruan Kota Yogyakarta. Jurnal Kajian Bimbingan Dan Konseling, 2(4), 142-147.

Susantyo, B. (2018). Faktor-faktor determinan penyebab perilaku agresif remaja di permukiman kumuh di Kota Bandung. Sosio Konsepsia, 61), 1-17.

Trenas, R., Félix, A., Osuna, P., José, M., \& Herruzo Cabrera, J. (2009). La agresividad en la infancia: el estilo de crianza parental como factor relacionado. European Journal of Education and Psychology, 2(3), $211-222$.

Wicaksana, I. (2008). Mereka bilang aku sakit jiwa: refleksi kasus-kasus psikiatri dan problematika kesehatan jiwa di Indonesia. Yogyakarta: Kanisius.

Widiastuti, D., \& Sekartini, R. (2016). Deteksi dini, faktor risiko, dan dampak perlakuan salah pada anak. Sari Pediatri, 72$), 105-112$.

Wilburn, V. R., \& Smith, D. E. (2005). Stress, self-esteem, and suicidal ideation in late adolescents. Adolescence, 40 (157).

Wilson, J. J. (2003). Preventing adolescent gang involvement. Juvenile Justice Buletin, 26(2), 1-12.

Zulaiha, Z., Husen, M., \& Bakar, A. (2019). Analisis faktor penyebab perilaku agresif pada siswa. JIMBK: Jurnal Ilmiah Mahasiswa Bimbingan \& Konseling, 4(1). 